\title{
Biochemical effects of three commercial formulations of Bacillus thuringiensis (Agerin, Dipel 2X and Dipel DF) on Spodoptera littoralis larvae
}

\author{
Aida S. Kamel; Mona F. Abd-EL Aziz and Nehad M. EL-Barky \\ Benha Univ. Faculty of Science, Entomol. Dept - Benha- Egypt.
}

\begin{abstract}
Effectiveness of commercial formulations of Bacillus thuringiensis var Kurstaki "Agerin, Dipel 2X and Dipel DF" on total protein and lipid contents were studied. Activities of detoxification and metabolic enzymes were also measured in treated and control larvae of cotton leafworm Spodoptera littoralis. Collected samples from treated larvae at intervals of 48 and $120 \mathrm{hrs}$ post treatment were analyzed to assess the total protein and lipid contents as well as the enzymes activities. Significant reductions were observed in total protein content at $120 \mathrm{hrs}$ larvae in all treatments compared with control. In all larvae treated with Agerin and Dipel DF the lipid content was significantly elevated after 48 and 120 hrs of treatment while Dipel 2X showed no significant difference in lipid content. However, fluctuated changes in the enzymes activity of treated larvae were found. We conclude that there are differences in biochemical effects between various commercial formulations of Bacillus thuringiensis kurstaki. In most cases Agerin was found more effective on S. littoralis than others.
\end{abstract}

Key words: Bacillus thuringiensis, Spodoptera littoralis, protein, lipid, detoxification enzymes and metabolic enzymes.

\section{INTRODUCTION}

The Egyptian cotton leafworm, S. littoralis, is considered a destructive polyphagous pest to many agricultural crops specially cotton. Bt have shown high toxicity against $S$. littoralis (Salama \& Foda, 1982). Exposure of sublethal doses of the Cry toxin(s) greatly affects the biological activity and reproduction of the treated insects (Oron et al., 1985).

The most widely used microbial pesticides worldwide are those based on preparations of the bacterium Bacillus thuringiensis (Bt) (Lambert \& Peferoen, 1992).

The toxicity of $B t$ is due to the production of crystalline protein protoxins, known as $\delta$-endotoxins (Broderick et al., 2006). Solubilized protoxins are activated by midgut proteases and bounded with the receptors of the epithelial cells (Pigott and Ellar, 2007). The toxins insert themselves into the cell, where they form pores that lead to cell lysis, subsequently causing insect death (de Maagd et al., 2003). Commercial Bt products generally consist of a mixture of spores and crystals, produced in large fermenters and applied as foliar sprays, much like synthetic insecticides. (Sanchis et al., 1999).

The activities of enzymes such as alkaline phosphatase (ALP), glutamate oxaloacetate transaminase (GOT), glutamate pyruvate transaminase (GPT) and lactate dehydrogenase $(\mathrm{LDH})$ are parameters widely used in the diagnosis of diseases as these could give indications of progressive toxicity long before the actual manifestation of the toxic effects (Hanley et al., 1986).

The goal of this study was to compare the effects of Egyptian Bt biopesticide with other commercial formulations, Agerin, Dipel 2Xand Dipel DF, against larvae of 
S. littoralis with reference to their effects on enzyme activities as well as lipid and protein contents.

\section{MATERIALS AND METHODS}

\section{Tested Insects:-}

A laboratory strain of cotton leafworm S. littoralis (Lepidoptera- Noctuidae) was obtained from Plant Protection Research Institute, Agricultural Research Centre, Cairo, Egypt. Insects were reared on castor bean leaves in laboratory under constant conditions of $27 \pm 2{ }^{\circ} \mathrm{C}$, photoperiod of $14 \mathrm{hrs} \mathrm{light} \mathrm{and} 10 \mathrm{hrs}$ dark and $65 \pm 5 \%$ R.H.

The culture of the cotton leaf worm, Spodoptera littoralis ( Boisd ) was initiated from freshly collected eggs masses supplied from the division of cotton leaf worm of plant protection research Institute, Dokki, Egypt. All stages of Spodoptera littoralis were cultured and tested at $27 \pm 2^{\circ} \mathrm{C}$ and $70 \pm 5 \%$ R.H. Larval stages were reared on caster bean leaves which were provided daily.

\section{Bacillus thuringiensis:}

The three commercial formulations were obtained from Plant Protection Research Institute, Agricultural Research Centre, Cairo, Egypt. Agerin 6.5\%, Dipel 2 X $6.4 \%$ and Dipel DF $54 \%$.

\section{Experiments:}

\subsection{Bioassay tests:}

Leaf-dip bioassay method was followed as described by Tabashnik et al., (1991) using castor leaves. The leaves were first washed with distilled water and dipped in solutions of different concentrations of Bt commercial formulations (Agerin, Dipel 2X and Dipel DF) prepared with distilled water. Each leaf was dipped for 510 second and allowed to air dry for a period of one hour. The leaves were then placed individually into Petri dishes (15 cm diameter). Newly hatched second instar larvae were released on each dish with three replications (twenty insects /replicate) including controls. There were eight concentrations ranging from $0.33-0.01 \%$ to Agerin and Dipel 2X and $2.70-0.08 \%$ to Dipel DF. Larvae were allowed to feed for $48 \mathrm{hr}$ on treated leaves. Then these leaves were removed and replaced by another untreated ones. Larval mortality was recorded at 48 hrs. Probit analysis (Finney 1971) was used to estimate $\mathrm{LC}_{50}$ value.

\subsubsection{Biochemical Analysis:}

Sixty newly hatched second instar larvae were treated as previously described (twenty larvae / three replicates) with the $\mathrm{LC}_{50}$ of Agerin, Dipel $2 \mathrm{X}$ and Dipel DF for $48 \mathrm{hrs}$. Then treated leaves were removed and replaced by another untreated ones for $120 \mathrm{hrs}$. Twenty larvae per treatment and control were randomly selected for each time interval (48 and $120 \mathrm{hrs}$ ) to estimate lipid and protein contents. Activities of metabolic enzymes (GPT), (GOT) and (LDH) and detoxification enzymes [alkaline phosphatase (ALP), acid phosphatase (ACP) and phenoloxidase] were also estimated. Analysis of protein and lipid were carried out by methods described by Bradford (1976) and Knight et al. (1972), respectively. ALP and ACP activities were measured as described by (Powell \& Smith, 1954) using disodium phenylphosphateas substrate. Phenoloxidase activity assayed according to a modification of Ishaaya (1971) using catechol as the substrate. GPT and GOT were determined according to the method of (Reitman \& Frankle, 1957). The estimated LDH was done as described by Randox kit (Randox laboratories td., United Kingdom) using an optimized standard method according to the recommendation of Deutschen Gessellschaft fur Klinische chemie (DGCK 1970). Means were tested for 
significance by the one way analysis of variance (ANOVA). When the ANOVA statistics were significant $(\mathrm{P} \leq 0.01)$, means were compared by the Duncan's multiple range test.

\section{RESULTS}

Toxicity of three commercial formulations of $B t$ was evaluated against second instar larvae of the $S$. littoralis by leaf dip bioassay (Table 1). $48 \mathrm{hrs}$. median lethal concentrations $\left(\mathrm{LC}_{50}\right)$ of Agerin, Dipel $2 \mathrm{X}$ and Dipel DF were $0.18,0.069$ and $0.10 \%$, respectively.

Table (1): Toxicity of commercial formulations of Bacillus thuringiensis to S. littoralis after $48 \mathrm{~h}$ of exposure.

\begin{tabular}{|c|c|}
\hline Bt commercial formulations & $\mathrm{LC}_{50} \%$ \\
\hline Agerin & 0.18 \\
\hline Dipel 2X & 0.069 \\
\hline Dipel DF & 0.10 \\
\hline
\end{tabular}

Results in Table (2) revealed no different values of protein contents between control and treated larvae after $48 \mathrm{hrs}$ of exposure to different commercial formulations of Bt. A significant reduction was observed at $120 \mathrm{hrs}$ larvae in all treatments compared with the control. In all larvae treated with Agerin and Dipel DF the lipid content was significantly elevated after 48 and $120 \mathrm{hrs}$ of treatment. Dipel $2 \mathrm{X}$ showed no significant difference in lipid content from the control.

Table (2): Total protein and lipid contents of S. littoralis larvae after the treatment with different commercial formulation of Bacillus thuringiensis.

\begin{tabular}{|c|c|c|c|c|}
\hline \multirow{2}{*}{ Bt commercial formulation* } & \multicolumn{2}{|c|}{$\begin{array}{c}\text { Protein } \\
\text { (mg/g. b.wt)** } \\
\text { ( Mean } \pm \text { S.E) }\end{array}$} & \multicolumn{2}{c|}{$\begin{array}{c}\text { Lipids } \\
\text { (mg/g. b.wt) } \\
\text { (Mean } \pm \text { S.E) }\end{array}$} \\
\cline { 2 - 5 } & $48 \mathrm{~h}$ & $120 \mathrm{~h}$ & $48 \mathrm{~h}$ & $120 \mathrm{~h}$ \\
\hline Control & $49.27 \pm 0.61^{\mathrm{a}}$ & $34.23 \pm 0.67^{\mathrm{a}}$ & $16.54 \pm 0.35^{\mathrm{b}}$ & $12.11 \pm 0.35^{\mathrm{b}}$ \\
\hline Agerin & $49.67 \pm 1.17^{\mathrm{a}}$ & $27.05 \pm 0.15^{\mathrm{b}}$ & $20.27 \pm 1.15^{\mathrm{a}}$ & $16.77 \pm 0.64^{\mathrm{a}}$ \\
\hline Dipel 2X & $48.9 \pm 0.56^{\mathrm{a}}$ & $28.50 \pm 0.29^{\mathrm{b}}$ & $14.48 \pm 0.44^{\mathrm{b}}$ & $13.35 \pm 0.44^{\mathrm{b}}$ \\
\hline Dipel DF & $50.9 \pm 0.3^{\mathrm{a}}$ & $27.43 \pm 0.73^{\mathrm{b}}$ & $19.2 \pm 0.8^{\mathrm{a}}$ & $17.54 \pm 0.73^{\mathrm{a}}$ \\
\hline
\end{tabular}

Vertically means bearing different letters are significantly different at $\mathrm{P} \leq 0.01$.

$* 2^{\text {nd }}$ larval instars treated with $\mathrm{LC}_{50}$ of Agerin, Dipel $2 \mathrm{X}$ and Dipel DF. (0.18, 0.069 and $0.10 \%$, respectively)

** b.wt = body weight.

Differences in metabolic enzymes activities (GPT, GOT and LDH) between the control and treated larvae are shown in Table (3). Results revealed no different values in GPT and LDH activities between control and infected larvae after $48 \mathrm{~h}$ of exposure. At the same interval GOT activity was significantly higher in treated larvae with Agerin compared with the control and other treatments. But its activity significantly decreased in larvae treated with Dipel $2 \mathrm{X}$ and Dipel DF than those treated with Agerin. There were significant increases in GPT and GOT activities at $120 \mathrm{hrs}$, of larvae treated with Dipel 2X and Agerin. Whereas the activity of LDH was 
significantly lower in larvae treated with Dipel $2 \mathrm{X}$ and Dipel DF than those treated with Agerin and control.

Table (3): Metabolic enzymes activities of S. littoralis larvae after the treatment with different commercial formulation of Bacillus thuringiensis

\begin{tabular}{|c|c|c|c|c|c|c|}
\hline $\begin{array}{l}\text { Bt commercial * } \\
\text { formulations* }\end{array}$ & \multicolumn{2}{|c|}{$\begin{array}{c}\text { GPT } \\
\left(\mathrm{U}^{* *} \times 10^{3} / \text { g.b.wt. }\right)^{* * *} \\
(\text { Mean } \pm \text { S.E })\end{array}$} & \multicolumn{2}{|c|}{$\begin{array}{c}\text { GOT } \\
\left(\mathrm{U} \times 10^{3} / \text { g.b.wt. }\right) \\
(\text { Mean } \pm \text { S.E }) \\
\end{array}$} & \multicolumn{2}{|c|}{$\begin{array}{c}\text { LDH } \\
\left(\mathrm{U} \times 10^{3} / \text { g.b.wt. }\right) \\
(\text { Mean } \pm \text { S.E }) \\
\end{array}$} \\
\hline Control & $2627 \pm 36.59^{\mathrm{a}}$ & $1397.67 \pm 82.60^{\mathrm{b}}$ & $1693 \pm 20.41^{b}$ & $1840 \pm 30.55^{\mathrm{b}}$ & $15196.7 \pm 347.4^{\mathrm{a}}$ & $4750 \pm 145.1^{\mathrm{a}}$ \\
\hline Dipel 2X & $2626.33 \pm 63.60^{\mathrm{a}}$ & $2293.33 \pm 99.38^{\mathrm{a}}$ & $1430 \pm 41.93^{\mathrm{cb}}$ & $1678.33 \pm 26.91^{\mathrm{bc}}$ & $14225.7 \pm 243.5^{\mathrm{a}}$ & $3428.7 \pm 212.9^{b}$ \\
\hline Dipel DF & $2590.67 \pm 92.4^{\mathrm{a}}$ & $1468.5 \pm 51.5^{\mathrm{b}}$ & $1479.33 \pm 55.56^{\mathrm{cb}}$ & $1635.0 \pm 65.0^{\mathrm{bc}}$ & $15730 \pm 178.7^{\mathrm{a}}$ & $3036.5 \pm 83.5^{b}$ \\
\hline
\end{tabular}

Vertically means bearing different letters are significantly different at $\mathrm{P} \leq 0.01$.

$* 2^{\text {nd }}$ larval instars treated with $\mathrm{LC}_{50}$ of Agerin, Dipel $2 \mathrm{X}$ and Dipel DF. (0.18, 0.069 and $0.10 \%$, respectively)

$* * \mathrm{U}=$ unit of enzyme activity. $\quad * * *$ b.wt = body weight

Effects of the three commercial formulations of $B t$ on detoxification enzymes phenoloxidase, ALP and ACP are shown in. Table (4). Activity level of ALP enzyme in $48 \mathrm{hrs}$ post-treatment decreased significantly in all treatments than the control. The highest activity was observed in case of larvae infected with Agerin and Dipel DF.after 120 hrs.

Table: (4): Detoxification enzymes activities of S. littoralis larvae after the treatment with different commercial formulation of Bacillus thuringiensis

\begin{tabular}{|c|c|c|c|c|c|c|}
\hline \multirow{2}{*}{ Bt commercial * formulations* } & \multicolumn{2}{|c|}{$\begin{array}{c}\text { ALP } \\
\left(\mathrm{U}^{* *} \times 10^{3} / \mathrm{gm} / \mathrm{b} . \mathrm{wt}\right) * * * \\
(\text { Mean } \pm \text { S.E) }\end{array}$} & \multicolumn{2}{|c|}{$\begin{array}{c}\text { ACP } \\
\left(\mathrm{U} \times 10^{3} / \mathrm{gm} / \mathrm{b} . \mathrm{wt}\right) \\
(\text { Mean } \pm \text { S.E })\end{array}$} & \multicolumn{2}{|c|}{$\begin{array}{c}\text { Phenoloxidase } \\
\left(\mathrm{U} \times 10^{3} / \text { g.b.wt. }\right) \\
(\text { Mean } \pm \text { S.E })\end{array}$} \\
\cline { 2 - 7 } & $48 \mathrm{~h}$ & $120 \mathrm{~h}$ & $48 \mathrm{~h}$ & $120 \mathrm{~h}$ & $48 \mathrm{~h}$ & $120 \mathrm{~h}$ \\
\hline Control & $576.3 \pm 10.0^{\mathrm{a}}$ & $99.0 \pm 3.5^{\mathrm{c}}$ & $143.67 \pm 1.5^{\mathrm{a}}$ & $48.32 \pm 1.2^{\mathrm{c}}$ & $21.64 \pm 0.39^{\mathrm{c}}$ & $15.77 \pm 0.34^{\mathrm{a}}$ \\
\hline Agerin & $436.33 \pm 3.7^{\mathrm{b}}$ & $185.67 \pm 3.9^{\mathrm{a}}$ & $122 \pm 5.5^{\mathrm{b}}$ & $82.54 \pm 2.3^{\mathrm{a}}$ & $29.38 \pm 0.76^{\mathrm{a}}$ & $6.02 \pm 0.32^{\mathrm{c}}$ \\
\hline Dipel 2X & $298.67 \pm 2.3^{\mathrm{c}}$ & $79.33 \pm 2.7^{\mathrm{c}}$ & $84.0 \pm 2.1^{\mathrm{c}}$ & $53.74 \pm 2.8^{\mathrm{bc}}$ & $25.95 \pm 0.30^{\mathrm{b}}$ & $11.95 \pm 0.18^{\mathrm{b}}$ \\
\hline Dipel DF & $432.0 \pm 6.0^{\mathrm{b}}$ & $140.5 \pm 7.5^{\mathrm{b}}$ & $120.0 \pm 2 .^{\mathrm{b}}$ & $61.41 \pm 2.8^{\mathrm{bc}}$ & $22.49 \pm 049^{\mathrm{c}}$ & $5.34 \pm 0.49^{\mathrm{c}}$ \\
\hline
\end{tabular}

Vertically means bearing different letters are significantly different at $\mathrm{P} \leq 0.01$.

$* 2^{\text {nd }}$ larval instars treated with $\mathrm{LC}_{50}$ of Agerin, Dipel $2 \mathrm{X}$ and Dipel DF. (0.18, 0.069 and $0.10 \%$, respectively)

$* * \mathrm{U}=$ unit of enzyme activity. $\quad * * *$ b.wt = body weight

The activity of this enzyme reached its highest level in larvae treated with Agerin followed by Dipel DF, while Dipel $2 \mathrm{X}$ did not show significant difference from control. ACP activity decreased significantly in all treated larvae after $48 \mathrm{hrs}$. of exposure than the control. No significant difference was observed between larvae infected with Agerin and Dipel DF. The highest activity of ACP was observed after $120 \mathrm{hrs}$ of exposure to Agerin but no difference was observed in Dipel DF and Dipel 
2X treated larvae than the control. After 48 hrs of infection phenoloxidase had a greater activity level in larvae infected with Agerin followed by Dipel 2X. No significant difference was observed in its activity in larvae treated with Dipel DF and control. In contrast, after $120 \mathrm{hrs}$ the phenoloxidase activity decreased in larvae treated with Agerin and Dipel DF than those of control which recorded the highest activity than all treated larvae.

\section{DISCUSSION}

Treatment of $S$. Littoralis larvae with the $\mathrm{LC}_{50}$ of the commercial formulations of Bt (Agerin, Dipel 2X and Dipel DF) induced considerable changes in physiological and biochemical parameters which studied in this paper.

Protein has been shown to affect important individual-level fitness-associated traits such as body size, growth rate, and fecundity; and at higher levels of organization has been linked to population dynamics, life histories, and even biological diversification (Fagan et al., 2002). Etebari (2006) showed that many insecticides decreased feeding efficiency and protein amount of an insect's body. Our results showed a significant reduction of protein after $120 \mathrm{hrs}$ of exposure in all treatments than the control and this observation agreement with El-Shershaby et al,. (2008) who found that Dipel 2X gradually suppress protein synthesis as post treatment period increase and reached its maximum effect after120 hrs. Nath et al., (1997) suggested that this could be due to the break down of protein into amino acids, so with the entrance of these amino acids to TCA cycle as a keto acid, they will help to supply energy for the insect. So, protein depletion in tissues may constitute a physiological mechanism and might play a role in compensatory mechanisms under insecticidal stress to provide intermediates to the krebs cycle by retaining free amino acid content in hemolymph. In contrast to this conclusion (Narayan \& Jayaraj, 1974) observed that infected larvae of $S$. littoralis with $B t$ induced a significant hyperproteinia. This can be attributed to stimulate synthesis of protein producing factors in insects as the protein requirement was increased for of $B t$ spores.

Lipids are the most suitable materials for storage of energy reserves. Compared to carbohydrates, lipids can supply as much as eight times more energy per unit weight (Beenakkers et al., 1985). In this study, Agerin and Dipel DF showed high significant elevation in lipid contents in infected larvae after 48 and $120 \mathrm{hrs}$ of treatment than the control. Similarly lipid content in tobacco cutworm Spodoptera litura (fab.) larvae was studied by Tripathi \& Singh (2002), the infection resulted in significant reduction in total lipid content of haemolymph in $3^{\text {rd }}, 4^{\text {th }}$ and $5^{\text {th }}$ instars infected larvae. They suggested that the reason for the lower fat content in infected larvae could be the extended larval period of the treated insects and blocked food ingestion, and the fat reserves might have been utilized for the maintenance during extended larval period.

Transaminases (GPT and GOT) enzymes help in the production of energy (Azmi et al., 1998). GOT and GPT serve as a strategic link between the carbohydrates and protein metabolism and are known to be altered during various physiological and pathological conditions (Etebari et al., 2005). The activity of both GPT and GOT increased in larvae infected with Agerin and Dipel 2X at 48 and $120 \mathrm{hrs}$ of treatment. El-Shershaby et al., (2008) found fluctuated changes in the activity of GPT and GOT of S. littoralis larvae infected with Dipel $2 X$. The GPT activity was clearly decreased after 48 and $72 \mathrm{hrs}$. of treatment than in the untreated. The post-treatment period increased to 120 hrs., GPT enzyme activity detected the highest positive change. They 
suggested that this may be attributed to the occurrence of reversible binding between pesticides and enzymatic site of action on the enzyme surface.

LDH is an important glycolytic enzyme that is present in virtually all tissues (Kaplan \& Pesce, 1996). It is involved in carbohydrate metabolism and has been used as an indicative criterion of exposure to chemical stress (Diamantino et al., 2001). In this study the activity level of lactate LDH was significantly lower in larvae treated with Dipel 2X and Dipel DF than those treated with Agerin and control after 120h of infection. Nathan et al. (2005) showed that feeding of Spodoptera litura on Ricinus communis L. treated with azadirachtin (plant extraction) and nucleopolyhedrovirus decreases the amount of this enzyme in midgut that demonstrates low nutritional efficiency of the larvae. Similar results were also observed on effectiveness of Melia azedarach on rice leaffolder (Nathan, 2006). The higher enzyme activity in the midgut of control insects is most probably due to consumption as well as utilization of large quantities of food. Imbalance in enzyme-substrate complex and inhibition of peristaltic movement of the gut might have inhibited the enzyme activity in the treated insects (Nathan et al., 2005).

ALP and ACP are hydrolytic enzymes, which hydrolyse phosphomonoesters under acid or alkaline conditions, respectively. ALP is mainly found in the intestinal epithelium of animals and its primary function is to provide phosphate ions from mononucleotide and ribonucleo-proteins for a variety of metabolic processes. ALP is involved in the transphosphorylation reaction (Etebari et al., 2005). The present study showed that ALP and ACP activities decreased significantly after 48 hrs. postinfection in all treatments compared to the control. In the same time the activity of these enzymes didn't have significant difference in larvae treated with Agerin and Dipel DF. After $120 \mathrm{hrs}$ of Bt exposure invert changes were observed in the activity of ALP and ACP. The maximal elevation of activities of these enzymes was obtained by Agerin. Changes in ALP and ACP activities after treatment with Bt indicate that changing the physiological balance of the midgut might affect these enzymes.

Phenoloxidase is important components of insect immune systems. Phenoloxidase activity has been shown to correlate with resistance to some parasites/pathogens across species (Nigam et al., 1997).

Our results showed that after $48 \mathrm{hrs}$ phenoloxidase had a greater activity level in larvae treated with Agerin followed by Dipel2X. In contrast, after 120 hrs. the phenoloxidase activity decreased in larvae treated with Agerin than those of control which recorded the highest activity than all treated larvae. Upon entry of bacteria into the insect hemolymph, the prophenoloxidase (proPO) system is activated by a cascade of serine proteases (Aspan \& Soderhall, 1991) and proPO components are released from insect hemocytes into the hemolymph. In this system two enzymes are activated. One is the enzyme ppA (prophenoloxidase activating enzyme), which converts inactive prophenoloxidase into active phenoloxidase (PO). Active phenoloxidase in turn converts tyrosine to dihydroxyphenyalanine, which binds to bacterial cell surfaces and triggers production of melanin (melanization). (Chattopadhyay, 2004) Conclusion and Recommendation:

It could be concluded that Agerin has more significant biochemical and physiological affects on larvae of Spodoptera littoralis than the other commercial formulations Dipel 2x and Dipel DF. The difference in activity might be due to the presence or absence of biologically active Cry toxins, their relative amounts and additive/synergistic effect of these toxins in the formulations, and batches of products Shelton et al., (1993). 
Agerin is the best using Bt biopesticide due to its efficacy and harmless to human health and environment.

\section{REFERENCES}

Aspan, A. and Soderhall, K. (1991). Purification of prophenol oxidase of crayfish blood cells and its activation by an endogenous Ser protease. Insect Biochemistry, 21: 363-373.

Azmi, M.A.; Sayed, N.H. and Khan, M.F. (1998). Comparative toxicological studies of RB-a (Neem Extract) and Coopex (Permethrin + Bioallethrin) against Sitophilus oryzae with reference to their effects on oxygen consumption and Got, Gpt activity. Journal of Zoology, 22: 307-310.

Beenakkers, A.M.Th.; van der Horst, D.J. and van Marrewijk, W. J. A. (1985). Biochemical processes directed to flight muscle metabolism. In: G. A. Kerkut and L. I. Gilbert (eds.), Comparative Biochemistry and Physiology, 10: $451-486$.

Bradford, M.M. (1976). A rapid and sensitive method for the quotation of microgram quantities of protein utilizing the principle of protein-dye binding. Analytical Biochemistry, 72: 248-254.

Broderick, A.N.; Raffa, K.F. and Handelsman, J. (2006). Midgut bacteria required for Bacillus thuringiensis insecticidal activity. Proceeding of National Academic Science USA, 103:15196-15199.

Candas, M.; Loseva, O.; Oppert, B.; Kosaraju, P. and Bulla, L.A. (2003). Insect resistance to Bacillus thuringiensis: alterations in the Indian meal moth larval gut proteome. Molecular \& Cellular Proteomic, 2:19-28.

Chattopadhyay, A.; Bhatnagar, N.B. and Bhatnagar, R. (2004). Bacterial Insecticidal Toxins. Critical Reviews in Microbiology, 30(1): 33-54.

de Maagd, R.A.; Bravo, A.; Berry, C.; Crickmore, N. and Schnepf, H.E. (2003). Structure, diversity, and evolution of protein toxins from spore-forming entomopathogenic bacteria. Annual Review Genetics, 37: 409-433.

Diamantino, T.C.; Amadeu, E.; Soaresa, M.V.M. and Guilherminoc, L. (2001). Lactate dehydrogenase activity as an effect criterion in toxicity tests with Daphnia magnaStraus. Chemosphere, 45:553-560.

DGCK, (1970). An optimized standard method for determining of lactate dehydrogenase. J. Clinical Chemistry \& Clinical Biochemistry, 8:658-667.

Downer, R.G.H. (1985). Lipid metabolism. In: Kerkut, G.A., Gilbert, L.I. (Eds.), Comprehensive Insect Physiology, Biochemistry and Pharmacology. Pergamon, Oxford, pp. 77-114.

El-Shershaby, M.; Farag, N. A. and Ahmed, A. A. I. (2008). Impact of Bacillus thuringiensis on protein content and enzymes activity of Spodoptera littoralis. Research Journal of Agriculture and Biological Sciences, 4(6): 861-865.

Etebari, K. (2006). Biochemical changes in hemolymph of silkworm larvae due to pyripyroxyfen residue. Pesticide Biochemistry and Physiology, Doi: 10.1016/j.pestbp. 2006.08.005.

Etebari, K.; Mirhodeini, S. Z. and Matindoost, L., (2005). A study on intraspecific biodiversity of eight groups of silkworm (Bombyx mori) by biochemical markers. Insect Science, 12: 87-94.

Fagan, W.F.; Siemann, E.; Mitter, C.; Denno, R.F; Huberty, A. F.; Woods , H. A. and Elser, J. J. (2002). Nitrogen in insects: implications for trophic complexity and species diversification. American Naturalist, 160: 784-802. 
Finney, D. J. (1971). Probit analysis. $3^{\text {rd }}$ edition. Cambridge university press. 318 pp.

Hanley, K.S.; Schmidt, E. and Schmidt, F.M. (1986). Enzymes in Serum, their volume in diagnosis, pp 70-81. Charles Thomas, Springfield Illinois.

Hofte, H. and Whiteley, H. R. (1989). Insecticidal crystal proteins of Bacillus thuringiensis. Microbiological Review, 53:242-55.

Ishaaya, I. (1971). Observation on the phenolixidase system in the armored scales Aonidiella aurantii and Chrysomphalus aonidium. Comparative Biochemistry and Physiology, 39(B): 935-943.

Kaplan, L. A. and Pesce, A. J. (1996). Clinical Chemistry-theory Analysis and Correlation. Mosby-Year Book, MO, 609-610.

Knight, J.A.; Anderson, S. and Rawle, J. M. (1972). Chemical basis of the sulfophospho-vanilin reaction for estimating total serum lipid. Clinical Chemistry, 18:199-202.

Lambert, B. and Peferoen, M. (1992). Insecticidal promise of Bacillus thuringiensis. Facts and mysteries about a successful biopesticide. Bioscience. 42:112-122.

Nath, B. S.; Suresh, A.; Mahendra, V. B. and Kumar, R. P. (1997). Changes in metabolism in hemolymph and fat body of the silkworm, Bombyx mori L. in response to organophosphorus insaecticides toxicity. Ecotoxicology and Environmental Safety, 36:169-173.

Nathan, S.S. (2006). Effects of Melia azedarach on nutritional physiology and enzyme activities of the rice leaffolder Cnaphalcrocis medinalis (Guenee) (Lepidoptera: Pyralidae). Pesticide Biochemistry and Physiology, 84 (2): 98-108.

Nathan, S.S.; Kalaivani, K. and Chung, P.G. (2005). The effects of azadirachtin and nucleopolyhedrovirus on midgut enzymatic profile of $S$. litura Fab. (Lepidoptera: Noctuidae). Pesticide Biochemistry and Physiology, 83 (1): 46-57.

Nigam, Y.; Maudlin, I.; Welburn, S. and Ratcliffe, N.A. (1997). Detection of phenoloxidase activity in the hemolymph of tsetse flies, refractor and susceptible to infection with Trypanosoma brucei rhodesiense. Journal of Invertebrate Pathology, 69:279-281.

Pentreath, V. W. and Kennedy, G. E. (2004). Pathogenesis of human African trypanosomiasis. In: The Trypanosomiasis (eds. I. Maudlin, P. H. Holmes and Miles) CABI Publishing, 283-301pp.

Pigott, C.R. and Ellar, D.J. (2007) Role of receptors in Bacillus thuringiensis crystal toxin activity. Microbiology and Molecular Biology Reviews, 71:255-281.

Powell, M. E. A. and Smith, M.J.H. (1954). The determination of serum acid and alkaline phosphatase activity with 4-aminoantipyrine. J. Clinical Pathology, 7: 245-248.

Oron, U.; Sokolover, M.; Yawtez, A.; Sneh, B. and Honigman, A. (1985). Ultrastructure changes in the larval midgut epithelium of $S$. littoralis following ingestion of $\delta$-endotoxin of Bacillus thuringiensis var. entomocidus. Journal of Invertebrate Pathology, 45: 353-355.

Reitman, S. and Frankel, S. (1957). A colorimetric method for determination of serum glutamic oxaloacetic and glutamic pyruvic transaminases. American Journal of Clinical Pathology, pp. 28-56.

Salama, H. S. and Foda, M. S. (1982). A strain of Bacillus thuringiensis var. entomocidus with high potential activity on $S$. littoralis. Journal of Invertebrate Pathology, 39:110-111. 
Salama, H.S.; Morris, O.N. and Rached, E. (1993). The biopesticide Bacillus thuringiensis and its applications in developing countries. Proc. Inter. Workshop, NRC-Cairo, Agriculture Canada and IDRC, 4-6 November, 1991, pp. 339.

Sanchis, V.; Gohar, M.; Chaufaux, J.; Arantes, O.; Meier, A.; Agaisse, H .; Cayley, J. and Lereclus, D. (1999) Development and Field Performance of a BroadSpectrum Nonviable Asporogenic Recombinant Strain of Bacillus thuringiensis with Greater Potency and UV Resistance. Applied Environmintal Microbiology, 65(9): 4032- 4039.

Schmidt, G.H.; Ahmed, A.I. and Breuer. M. (1997). Effect of Melia azedarach extract on larlal development and reproduction parameters of $S$. littoralis (B.) and Agrotis ipsilon (H.) (Lep. Noctuidae). Phytoparasitica, 26 (4):164-172.

Shelton, A.M.; Robertson, J. L.; Tang, J.D.; Perez, C.; Eigenbrode, S.D.; Preisler, H.K.; Wilsey, W.T. and Cooley, R.J.(1993). Resistance of diamondbackmoth (Lepidoptera: Plutellidae) to Bacillus thuringiensis subspecies in the "eld. Journal of Economic Entomology, 86: 697-705.

Sneh, B.; Schuater, S.; Broza, M. (1981). Insecticidal activity of Bacillus thuringiensis strains against the Egyptian cotton leaf worm S. littoralis (Lep: Noctuidae). Entomophaga, 26:179-190.

Tabashnik, B.E.; Finson, N. and Johnson, M.W. (1991). Managing resistance to Bacillus thuringiensis: Lessons from the diamondback moth (Lepidoptera: Plutellidae). Journal of Economic Entomology, 84: 49-55

Tripathi, R. and Singh, N. P. (2002). Biochemical Alterations in the Haemolymph of Bacillus thuringiensis var. kurstaki (B.t.k.) Infected Larvae of S. litura (Fab). Asian J. Exp. Sci. 16 (1\&2): 35-39.

\section{ARABIC SUMMERY}

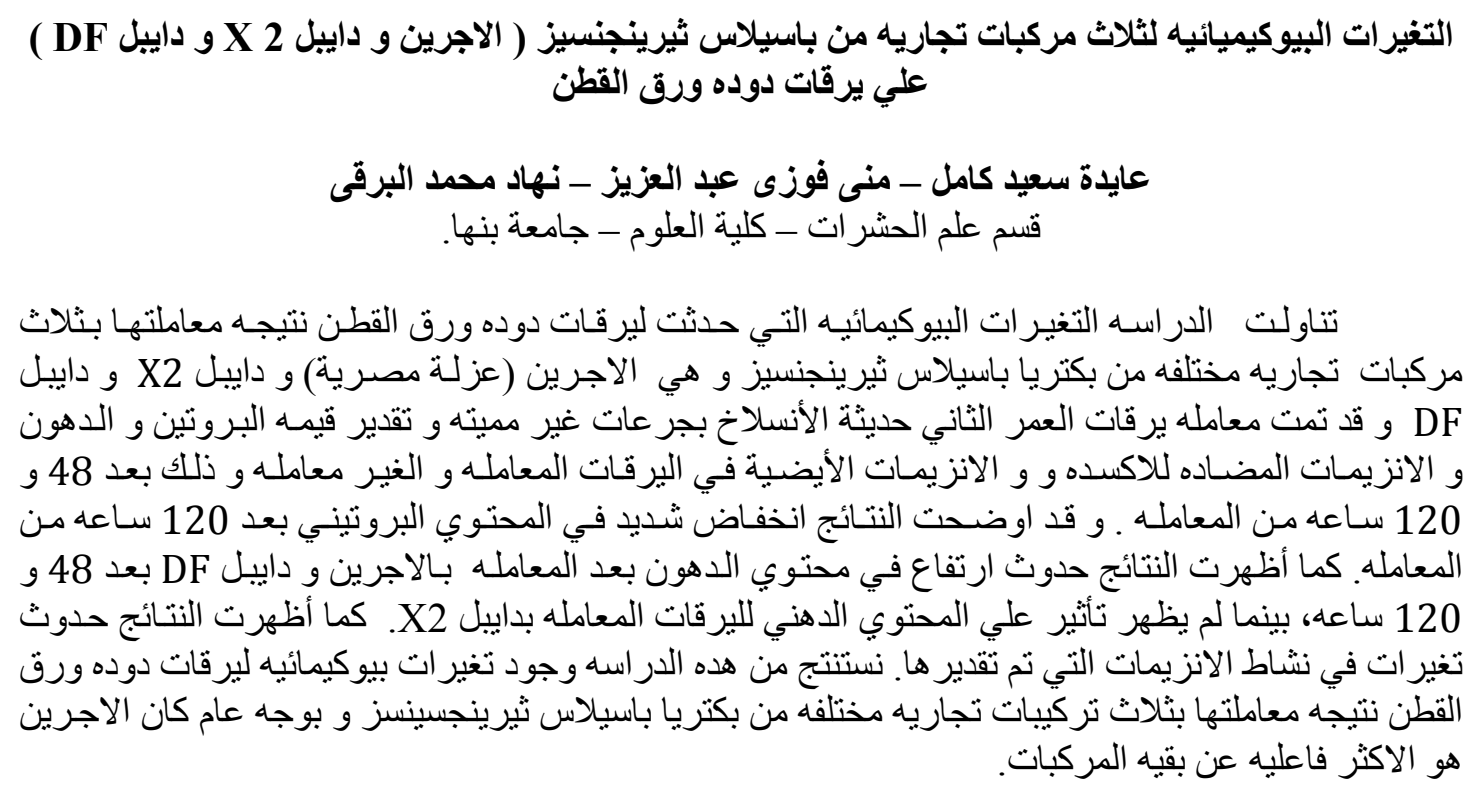

